\title{
Characterising hyperinsulinemia-induced insulin resistance in human skeletal muscle cells
}

\author{
Mark C Turner1,2,t, Neil R W Martin'1, Darren J Player ${ }^{3}$, Richard A Ferguson'1, Patrick Wheeler 1,2, Charlotte J Green4, \\ Elizabeth C Akam ${ }^{1}$ and Mark P Lewis ${ }^{1,2}$
}

1School of Sport, Exercise and Health Sciences, National Centre for Sport and Exercise Medicine, Loughborough University, Loughborough, UK 2University Hospitals of Leicester NHS Trust, Infirmary Square, Leicester, UK

3Division of Surgery and Interventional Science, Faculty of Medical Sciences, University College London, London, UK

${ }^{4}$ Drug Discovery Unit, School of Life Sciences, University of Dundee, Dundee, UK

Correspondence should be addressed to M C Turner: mark.turner@coventry.ac.uk

${ }^{\dagger}(\mathrm{M}$ C Turner is now at Centre for Sport, Exercise and Life Sciences, Faculty of Health and Life Sciences, Coventry University, Coventry, UK)

\begin{abstract}
Hyperinsulinaemia potentially contributes to insulin resistance in metabolic tissues, such as skeletal muscle. The purpose of these experiments was to characterise glucose uptake, insulin signalling and relevant gene expression in primary human skeletal muscle-derived cells (HMDCs), in response to prolonged insulin exposure (PIE) as a model of hyperinsulinaemia-induced insulin resistance. Differentiated HMDCs from healthy human donors were cultured with or without insulin (100 nM) for 3 days followed by an acute insulin stimulation. HMDCs exposed to PIE were characterised by impaired insulin-stimulated glucose uptake, blunted IRS-1 phosphorylation (Tyr612) and Akt (Ser ${ }^{473)}$ phosphorylation in response to an acute insulin stimulation. Glucose transporter 1 (GLUT1), but not GLUT4, mRNA and protein increased following PIE. The mRNA expression of metabolic (PDK4) and inflammatory markers (TNF- $\alpha$ ) was reduced by PIE but did not change lipid (SREBP1 and CD36) or mitochondrial (UCP3) markers. These experiments provide further characterisation of the effects of PIE as a model of hyperinsulinaemiainduced insulin resistance in HMDCs.

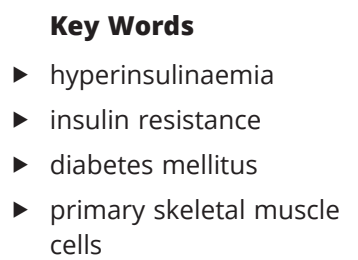
cells

\section{Introduction}

The inability to maintain glucose homeostasis in response to physiological insulin concentrations leads to an increase in blood glucose (hyperglycaemia) and consequently prolonged raised insulin concentrations (hyperinsulinaemia). Hyperinsulinaemia has been causally linked to the onset of diabetes in the early stages of the insulin resistance and in type 2 diabetes mellitus (Corkey 2012, Templeman et al. 2017), negatively affecting insulin-sensitive tissues such as liver, adipose and skeletal muscle (Page \& Johnson 2018). In humans, prolonged administration of insulin can attenuate insulin responsiveness, independent of hyperglycaemia. This would therefore suggest a potential role of hyperinsulinaemia as a cause of insulin resistance (Marangou et al. 1986, Del Prato et al. 1994).

In vitro research using human skeletal muscle-derived cells (HMDCs) has routinely been used to investigate various aspects of metabolic physiology (Aas et al. 2013). 
Consequently, it has been possible to investigate some of the cellular and molecular characteristics of skeletal muscle insulin resistance (Ciaraldi et al. 1995, Henry et al. 1995), as well as the potential causes of insulin resistance in skeletal muscle cells in response to other cells types, fatty acids and inflammatory cytokines (Dietze et al. 2002, Mäkinen et al. 2017).

Despite the development of relevant in vitro models to study metabolic disease, there is limited information regarding the effects of chronic insulin exposure on glucose metabolism in human skeletal muscle cells. Models of hyperinsulinaemia-induced insulin resistance through prolonged insulin exposure (PIE), using murine C2C12 skeletal muscle cells, have been shown to impair downstream insulin signalling and glucose uptake (Kumar \& Dey 2003, Turner et al. 2018, Cen et al. 2019). In addition, work in HMDCs has shown that exposure to a chronic insulin exposure can ablate the fractional velocity of glycogen synthase activity (Henry et al. 1996, Gaster et al. 2001) and, therefore, could contribute to the development of insulin resistance in skeletal muscle (Nikoulina et al. 1997).

Whilst previous literature has alluded to the physiological effects of hyperinsulinaemia-induced insulin resistance in human skeletal muscle tissue and primary cells (Del Prato et al. 1994, Gaster et al. 2001), currently the molecular characteristics which potentially underpin previously observed changes to PIE-induced insulin resistance are yet to be investigated. The aim of the current investigation was to determine how PIE would affect glucose uptake, insulin signalling and gene expression in HMDCs from healthy donors. In these experiments, it was found that PIE resulted in attenuated insulin signalling and glucose uptake; however, it did not alter the mRNA expression of genes involved in metabolism, which are putatively indicative of insulinresistant skeletal muscle.

\section{Methods}

\section{Participants}

Healthy male volunteers (age 24.4 \pm 1.1 years, height $1.78 \pm 0.04 \mathrm{~cm}$, weight $70.6 \pm 2.9 \mathrm{~kg}$, BMI $22.3 \pm 1.5 \mathrm{~kg} /$ $\mathrm{m}^{2}$ ) who did not report any family history of metabolic disease were recruited for this study. All procedures were conducted at Loughborough University, UK, under ethical approval and in accordance with the Declaration of Helsinki, 2008.

\section{Isolation and culture of human muscle-derived cells (HMDCs)}

Percutaneous skeletal muscle biopsies were obtained from the vastus lateralis by micro-biopsy technique (Acecut 11-gauge Biopsy Needle; TSK, Tochigi-Ken, Japan), as previously described (Ferguson et al. 2018). Skeletal muscle biopsies were scissor minced into small pieces, placed in tissue culture flasks coated in $0.2 \%$ Gelatin/PBS and maintained at $37^{\circ} \mathrm{C}$ and $5 \% \mathrm{CO}_{2}$ in growth media (GM, consisting of high glucose DMEM (Sigma) supplemented with 20\% foetal bovine serum (Pan Biotech UK Ltd, Dorset, UK) and 1\% penicillin/ streptomycin, Fisher Scientific). The HMDCs which migrated out of the muscle tissue and adhered to the tissue culture plastic were harvested and expanded through serial passages to increase cell numbers prior to experimentation. For experimentation, HMDCs were used between passages 3-7 (7-10 population doublings).

\section{Experimental protocol}

2500 cells $/ \mathrm{cm}^{2}$ of HMDCs were seeded into 12-well plates and cultured in GM until $80 \%$ confluent. Media was subsequently changed to low serum differentiation media (DM) which consisted of high glucose DMEM (Sigma) supplemented with $2 \%$ horse serum (Fisher Scientific) and $1 \%$ penicillin/streptomycin (Fisher Scientific). Following differentiation, (5-7 days) into multinucleate myotubes (as evidenced by light microscopy), cultures were subjected to prolonged insulin exposure (PIE), consisting of DM supplemented with the addition of $100 \mathrm{nM}$ human recombinant insulin (Sigma). Cultures were then serum starved for $4 \mathrm{~h}$ before being acutely stimulated with or without insulin (100 $\mathrm{nM})$ for $30 \mathrm{~min}$.

\section{Protein quantification and immunoblotting}

HMDCs were washed with PBS before being lysed in RIPA buffer (Sigma) containing a protease and phosphatase inhibitor cocktail mix (Fisher Scientific). Protein concentrations were determined using the Pierce $660 \mathrm{~nm}$ protein assay (Fisher Scientific), and thereafter samples were mixed with $4 \times$ Laemmli buffer (Bio-Rad), boiled for $5 \mathrm{~min}$ at $95^{\circ} \mathrm{C}$ and separated by SDS-PAGE. Proteins were transferred onto nitrocellulose membranes (Whatman Proton, Sigma-Aldrich) and blocked for $1 \mathrm{~h}$ at room temperature in 5\% BSA in TBST (Sigma) before being incubated with primary antibody overnight at $4^{\circ} \mathrm{C}$ in BSA or milk. Primary antibodies used for analysis 
were Akt (\#9272), phosphor Akt (Ser ${ }^{473) ~(\# 4060), ~}$ GSK-3 $\beta$ (\#9315), GSK-3 $\beta$ (Ser $\left.{ }^{9}\right)$ (\#9336), AS160 (Ser ${ }^{588)}$ (\#8730), glucose transporter 4 (GLUT4) (\#2213) and glyceraldehyde-3-phosphate dehydrogenase (GAPDH) (\#2118) purchased from Cell Signalling (NEB, Herts, UK). Glucose transporter 1 (GLUT1) (\#07-1401), insulin receptor substrate-1 (IRS-1) (\#05-784R) and phospho IRS-1 (Tyr $\left.{ }^{612}\right)$ (\#09-432) were purchased from Merck Millipore. Following overnight incubation, membranes were washed in TBST and subsequently incubated with anti-rabbit (\#7074) or anti-mouse (\#7076) horseradish peroxidaseconjugated secondary antibody (NEB, Herts, UK) at a concentration of 1:2000 in milk. Proteins were visualised using chemiluminescence substrate (Bio-Rad) and band densities were quantified using Quantity One image analysis software (Quality One 1-D analysis software version 4.6.8). Where appropriate, following visualisation of phosphorylated proteins, membranes were washed in TBST and incubated in stripping buffer (Fisher Scientific) before being blocked and probed as outlined previously for their corresponding total proteins. Phosphorylation was normalised to its corresponding total protein, with the exceptions of GLUT1, GLUT4 and AS160 (Ser ${ }^{588}$ ) which were normalised to GAPDH.

\section{RNA extraction and qPCR analysis}

RNA extraction was performed using TRI Reagent (Sigma) according to the manufacturer's instructions and quantified using UV spectroscopy (NanoDrop, Fisher Scientific). Gene expression was analysed by one-step RT-qPCR (Quantifast SYBR Green Mix (Qiagen)) using a Viia 7 thermocycler (Applied Biosystems). Each reaction consisted of $20 \mathrm{ng}$ of RNA in a final $10 \mu \mathrm{L}$ reaction volume (Qiagen). Master mixes were made according to the manufacturer's instructions using primers outlined in Table 1. Fluorescence was detected after every cycle
(40 cycles) and data were analysed using the $\Delta \Delta C_{t}$ method, using RNA polymerase II beta (POLR2B) as an endogenous control gene. Samples were normalised to each individual donor control sample, with each donor performed in duplicate for each condition, and each sample was ran in triplicate.

\section{Cell based glucose uptake assay}

HMDCs were plated into black, clear bottom 96-well plates (Fisher Scientific) and cultured as described in the experimental protocol. The measurement of 2-deoxyglucose (2DG) uptake was performed using a commercially available Glucose Uptake-Glo ${ }^{\mathrm{TM}}$ Assay kit (Promega). First, cultures were washed with PBS and incubated overnight in serum free media with/without 100 nM insulin. Briefly, HMDCs were washed with PBS before being stimulated with/without $1 \mathrm{nM}$ insulin in PBS. 0.1 M 2DG was added to all of the wells for $30 \mathrm{~min}$ at $25^{\circ} \mathrm{C}$. The reaction was arrested with the addition of stop and neutralization buffer, before the addition of 2DG6P detection reagent. Values were normalised to total protein concentration analysed on plates following glucose uptake measurement, using the Pierce $660 \mathrm{~nm}$ protein assay (Fisher Scientific).

\section{Statistical analysis}

Statistical analysis was performed using SPSS (version 23). Insulin signalling proteins were analysed by one-way ANOVA with Bonferroni post hoc correction. Differences in glucose uptake and gene expression between control and PIE conditions were analysed by independent samples $t$-test. The number of donors used for each analysis is outlined in the figure legends. Data are presented and mean \pm S.E.M. and statistical significance was set at $P<0.05$.

Table 1 Primer sequences of genes analysed by qPCR.

\begin{tabular}{l} 
Gene of interest \\
\hline RNA polymerase II \\
Glucose Transporter 4 \\
Hexokinase II \\
Pyruvate dehydrogenase lipoamide kinase isozyme 4 \\
Glucose Transporter 1 \\
Uncoupling protein 3 \\
Glycogen Synthase Kinase 3 beta \\
Tumour necrosis factor alpha \\
Insulin receptor substrate 1 \\
Cluster of differentiation 36 (Fatty acid translocase) \\
Sterol regulatory element binding protein factor 1
\end{tabular}

\begin{tabular}{l}
\hline Symbol \\
\hline POLR2B \\
GLUT4 (SLC2A4) \\
HKII \\
PDK4 \\
GLUT1 (SLC2A1) \\
UCP3 \\
GSK3- $\beta$ \\
TNF- $\alpha$ \\
IRS-1 \\
CD36 \\
SREBPF1 \\
\hline
\end{tabular}

\begin{tabular}{l}
\hline Manufacturer \\
\hline Sigma \\
Sigma \\
Qiagen \\
Sigma \\
Qiagen \\
Qiagen \\
Qiagen \\
Sigma \\
Qiagen \\
Sigma \\
Qiagen \\
\hline
\end{tabular}

Assertion No.

NM_000938

NM_001042

NM_000189

NM_002612

NM_006516

NM_003356

NM_001146156

NM_000594

NM 005544

NM_000072

NM_004176 


\section{Results}

Glucose uptake in human skeletal muscle cells following insulin exposure

To investigate the physiological effects of exposure to PIE, we measured glucose uptake using a commercially available assay. Acute insulin stimulation increased glucose uptake by approximately 1.5 fold in control HMDCs $(P<0.05$, Fig. 1A). However, HMDCs cultured with PIE exhibited no significant increase in glucose uptake following acute insulin stimulation $(P>0.05$, Fig. 1B).

Prolonged exposure to insulin alters phosphorylation of insulin signalling proteins IRS-1 (Tyr612)

Following evidence of altered glucose uptake following PIE, we analysed the phosphorylation of both Insulin receptor substrate 1 (IRS-1) and Akt as critical nodes of insulin signalling. Acute insulin stimulation significantly increased tyrosine phosphorylation of IRS-1 (Tyr $\left.{ }^{612}\right)$ above basal levels in control HMDCs $(P<0.01$, Fig. $2 \mathrm{~A})$. In contrast, we observed elevated basal IRS-1 (Tyr ${ }^{612}$ ) phosphorylation in PIE condition which was not increased further upon acute insulin stimulation $(P>0.05$, Fig. 2$)$. In addition, IRS-1 mRNA expression was analysed; however, it was not different between control and PIE conditions $(P>0.05$, Fig. 2B).

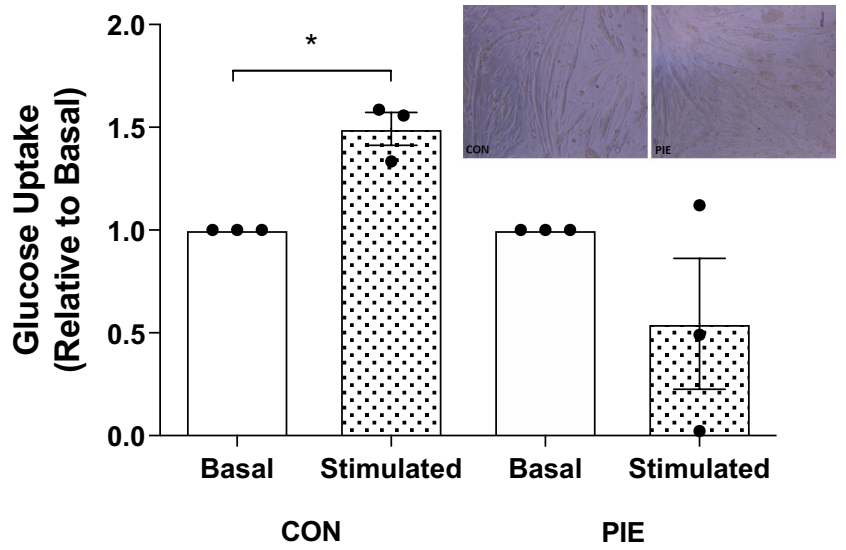

Condition

\section{Figure 1}

2-Deoxyglucose (2DG) uptake and phase contrast images of HMDCs cultured in control (CON) or prolonged insulin exposure (PIE) for 3 days. Cells were stimulated without (open bar) or with (doted bar) insulin. Data are mean \pm S.E.M. from three donors. *Significant difference between basal and stimulation $(P<0.05)$. A full colour version of this figure is available at https://doi.org/10.1530/JME-19-0169.
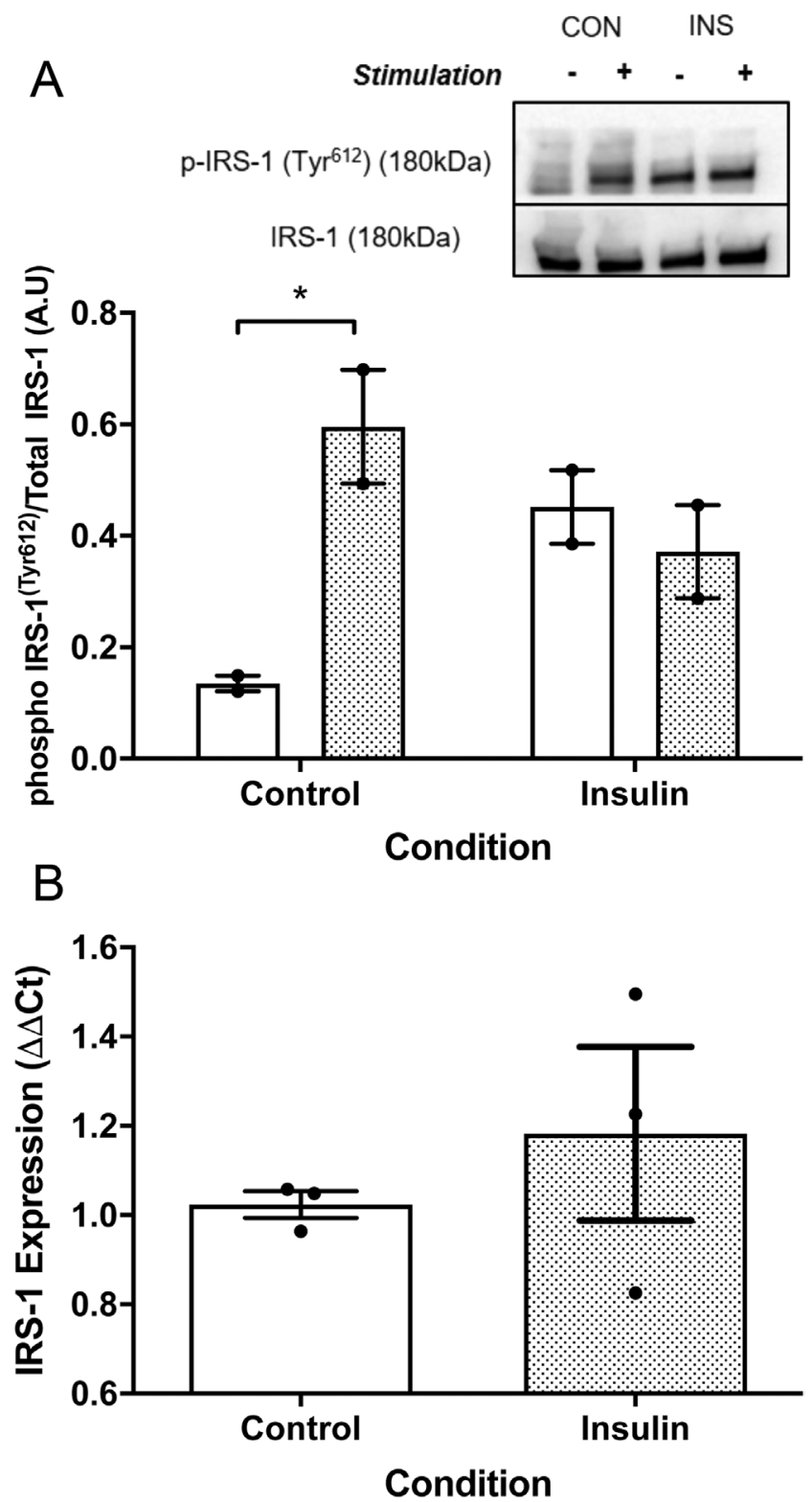

Figure 2

(A) IRS-1 phosphorylation (Tyr612) of HMDC cultured in CON or PIE media. Cells were stimulated without (open bar) or with (doted bar) insulin (100 $\mathrm{nM}$ ) for $30 \mathrm{~min}$. (B) IRS-1 mRNA expression $(\Delta \Delta \mathrm{Ct}$ ) of basal samples cultured in CON or PIE media. Data are mean \pm s.E.M. from two to four donors. *Significant difference between basal and acute insulin stimulation $(P<0.05)$.

\section{Prolonged exposure to insulin alters phosphorylation of Akt (Ser $\left.{ }^{473}\right)$}

Akt (Ser $\left.{ }^{473}\right)$ was responsive to acute insulin stimulation when HMDCs were cultured in control conditions $(P<0.05$; Fig. $3 \mathrm{~A})$; however, this response was blunted following PIE $(P>0.05$; Fig. $3 A)$. GSK-3 $\beta\left(\operatorname{Ser}^{9}\right)$ or AS160 (Ser ${ }^{588}$ ) phosphorylation was not different following 
acute stimulation or different between conditions (both $P>0.05$; Fig. 3B and C respectively).

\section{Exposure to insulin results in changes to GLUT1 but not GLUT4 mRNA and protein in HMDCs}

PIE increased the mRNA expression of GLUT1 by approximately 1.6 fold above HMDCs cultured in control conditions $(P<0.01$; Fig. $4 \mathrm{~A})$, but did not alter the mRNA expression of GLUT4 ( $P>0.05$; Fig. 4B). Protein expression analysis of GLUT1 was also increased in the PIE condition compared to CON $(P<0.05$; Fig. $4 \mathrm{C})$, but there was no difference in GLUT4 protein expression between conditions ( $P>0.05$; Fig. 4D).

\section{The effects of insulin exposure on the mRNA expression of metabolism markers}

Hexokinase II and pyruvate dehydrogenase kinase isoform 4 (PDK4), two enzymes which regulate glucose oxidation,

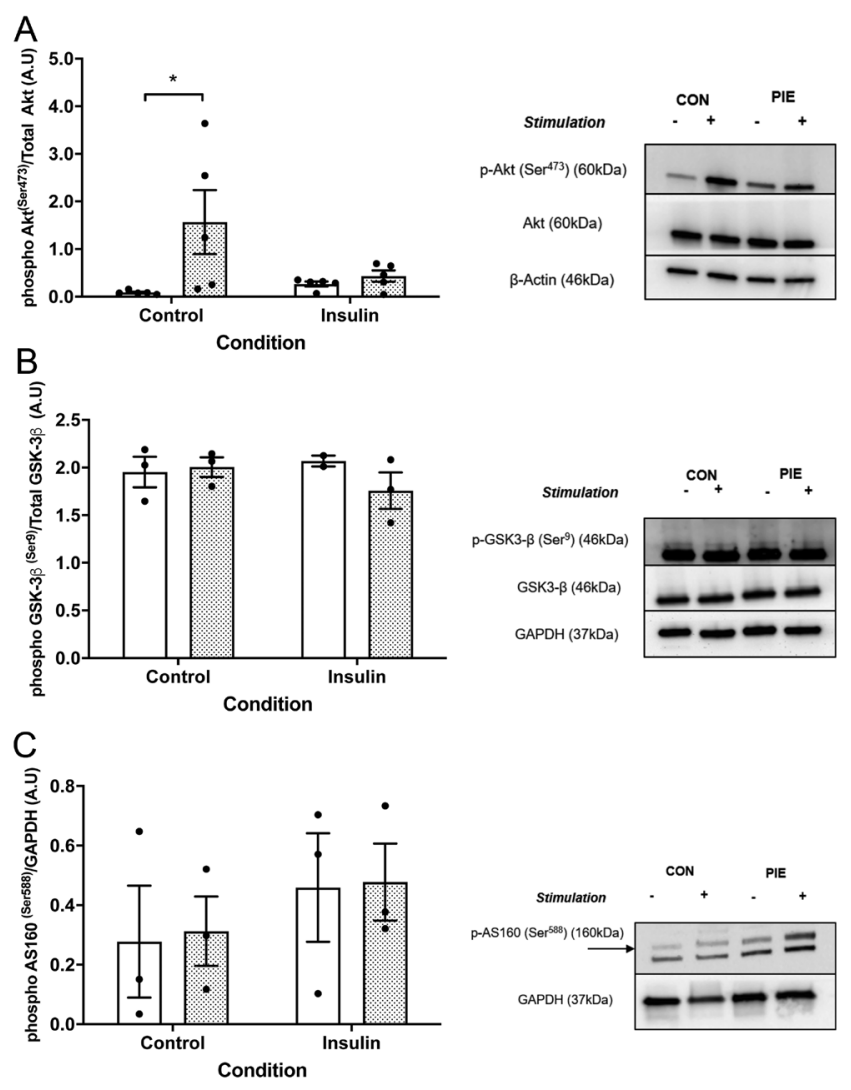

Figure 3

(A) Akt phosphorylation (Ser473), (B) GSK-3 $\beta$ phosphorylation (Ser ${ }^{9}$ ) of HMDC cultured in CON or PIE media, (C) AS160 phosphorylation (Ser ${ }^{588}$ ) of HDMC's cultured in CON or PIE media before being stimulated without (open bar) or with (doted bar) insulin (100 nM) for $30 \mathrm{~min}$. Data are mean \pm S.E.M. from two to five donors as represented by in the graph. *Significant difference between basal and acute insulin stimulation $(P<0.05)$.
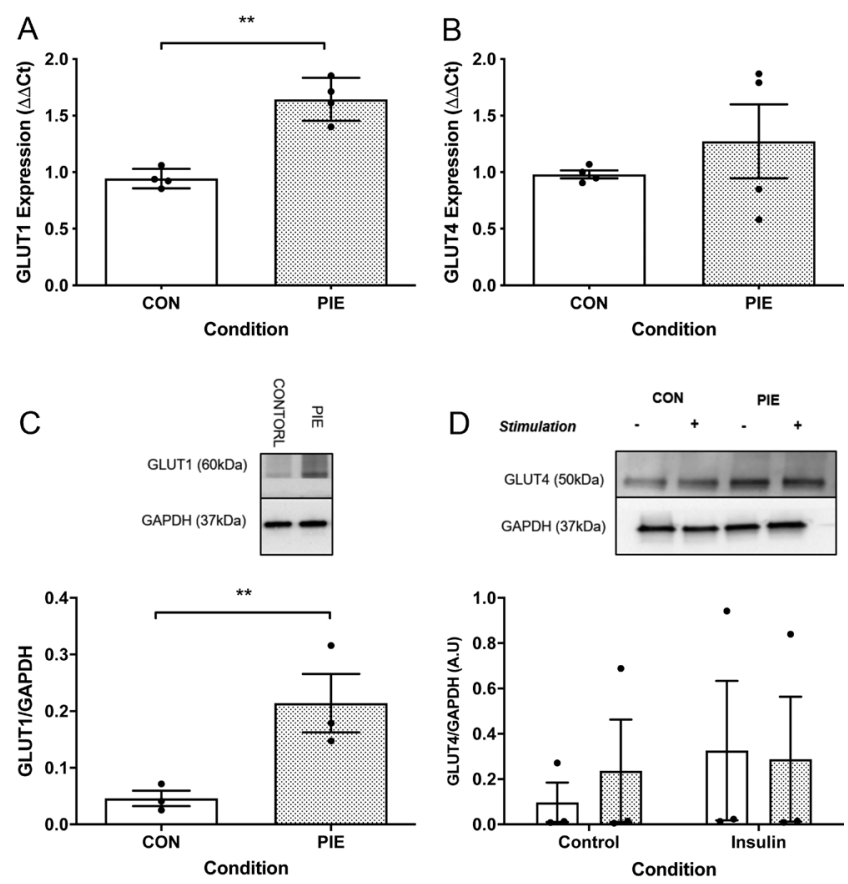

Figure 4

(A) Glucose transporter 1 (GLUT1) and (B) glucose transporter4 (GLUT4) mRNA expression ( $\Delta \Delta \mathrm{Ct}$ ). (C) GLUT1 protein expression and (D) GLUT4 protein expression normalised to GAPDH in HMDC cultured CON or PIE media. Data are mean \pm S.E.M. from three donors. Significant difference between conditions $* *(P<0.01)$.

have previously been shown to be regulated by insulin. Here, HKII mRNA expression did not change in HMDC's exposed to PIE ( $P>0.05)$; however, $P D K 4$ mRNA expression was significantly reduced following PIE $(P<0.01)$ and

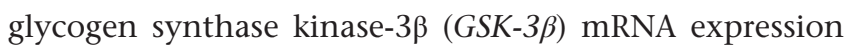
was increased following PIE, but did not reach statistical significance $(P=0.054)$. The mRNA expression of the lipid metabolism markers, sterol regulatory element-binding protein 1 (SREBP-1) and fatty acid translocase (cluster of differentiation $36(C D 36)$ ), was not different between conditions $(P>0.05)$. Similarly, the mRNA expression of mitochondrial uncoupling protein-3 (UCP3) was not different between conditions $(P>0.05)$. However, the mRNA expression of the pro-inflammatory marker TNF$\alpha$ was significantly lower in PIE compared to control $(P<0.05$, Fig. 5B).

\section{Discussion}

Hyperinsulinaemia is a symptom in the early stages of insulin resistance and type 2 diabetes mellitus (Shanik et al. 2008, Page \& Johnson 2018). To decipher how prolonged exposure to high concentrations of insulin could contribute to skeletal muscle insulin resistance, 


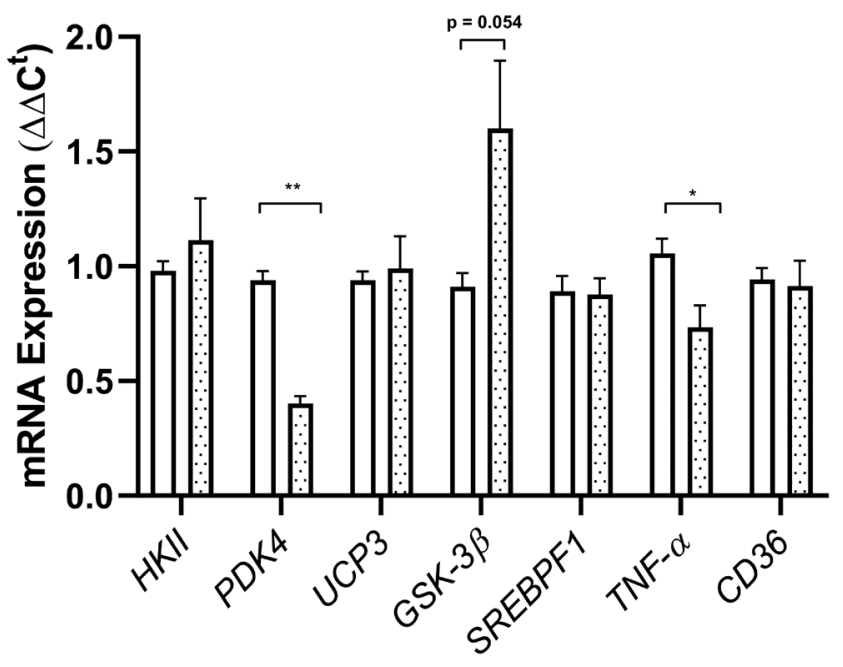

Gene of Interest

\section{Figure 5}

mRNA expression ( $\Delta \Delta \mathrm{Ct}$ ) of genes in HMDCs cultured CON or PIE media. Data are mean \pm S.E.M. from three to four donors. Significantly different between conditions * $(P<0.05)$, ** $(P<0.01)$.

in vitro experiments have been used to investigate some of the physiological effects of hyperinsulinaemia in cell lines (Kumar \& Dey 2003, Turner et al. 2018, Cen et al. 2019) and primary human skeletal muscle cells (Henry et al. 1996, Gaster et al. 2001). Our initial experiments used prolonged insulin exposure (PIE) as a model of hyperinsulinaemia and demonstrated that this was able to induce impaired glucose uptake in response to an acute insulin stimulation, thus confirming our own previous findings in C2C12 skeletal muscle cells (Turner et al. 2018) and those of Henry and colleagues who have shown hyperinsulinaemia to impair glucose synthase activity and insulin-stimulated glucose uptake in primary human skeletal muscle cells when chronically exposed to insulin (Ciaraldi et al. 1995) and as a phenomenon which occurs in both healthy and insulin-resistant skeletal muscle.

To examine the molecular responses to this impaired insulin-stimulated glucose uptake, we initially examined critical nodes of the insulin signalling cascade. Indeed, impaired insulin signalling contributes to skeletal muscle insulin resistance (Taniguchi et al. 2006). While the physiological changes in human skeletal muscle cells have been previously described (Henry et al. 1996, Gaster et al. 2001), we observed an attenuated IRS-1 phosphorylation (Tyr ${ }^{612}$ ) to acute insulin stimulation. This was due to an increase in basal phosphorylation which has previously be reported in rat skeletal muscle (Kanety et al. 1994). This response has been attributed to multisite phosphorylation of the insulin receptor in cell lines, including skeletal muscle (Kumar \& Dey 2003, Cen et al. 2019), although further experiments would be required to determine the phosphorylation sites in human skeletal muscle cells. The attenuation in the phosphorylation of Akt is indicative of insulin resistance (Krook et al. 1998a, Karlsson et al. 2005), which has been reported by our group, in C2C12 skeletal muscle cells following sustained exposure to insulin (Turner et al. 2018). In addition, while our findings did not show any changes in phosphorylation of downstream target AS160, its phosphorylation of multiple serine sites in response to insulin (Kramer et al. 2006) mean that further investigation is required to elucidate what sites are specifically inhibited following prolonged insulin.

Exposure to insulin can increase glucose transporter (GLUT) mRNA and protein expression (Walker et al. 1989, 1990), a finding which has also been shown in primary human skeletal muscle cells (Ciaraldi et al. 1995). The increase in expression is mostly likely due to an increase in GLUT1 mRNA and protein expression, which was increased following exposure to PIE in the present set of experiments. Basal glucose uptake has previously been observed in human (Ciaraldi et al. 1995) and murine skeletal muscle cells (Turner et al. 2018), and it is linked to the increase in GLUT1 mRNA and protein expression. In contrast, GLUT4 mRNA and protein expression were not altered in response to PIE, which has previously been reported in human skeletal muscle following hyperinsulinaemia-euglycaemia clamp (Postic et al. 1993). Despite contradictory findings in rodent skeletal muscle (Cusin et al. 1990), our findings provide further evidence that that hyperinsulinaemia is not a mediator of GLUT4 protein or mRNA expression in human skeletal muscle. Insulin regulates the expression of genes involved in skeletal muscle metabolism (Rome et al. 2003), of which the expression is altered in metabolic disease (Ducluzeau et al. 2001). HKII mRNA expression has previously been shown to be sensitive to insulin stimulation (Osawa et al. 1996), and its response is attenuated in insulin-resistant skeletal muscle (Ducluzeau et al. 2001). However, this is in contrast to our experiments, which may reflect the differences in metabolic demands of cells and tissues. The reduction in PDK4 mRNA expression in these experiments could be considered indicative of a physiological and not pathophysiological response to insulin in skeletal muscle (Kim et al. 2006, McAinch et al. 2015). In addition, a number of genes which are associated with skeletal muscle insulin resistance, such as SREBP1, CD36 and UCP3 (Krook et al. 1998b, Ducluzeau et al. 2001, Wallberg-Henriksson et al. 2007), were not altered in these experiments. This indicates that while hyperinsulinaemia can induce insulin 


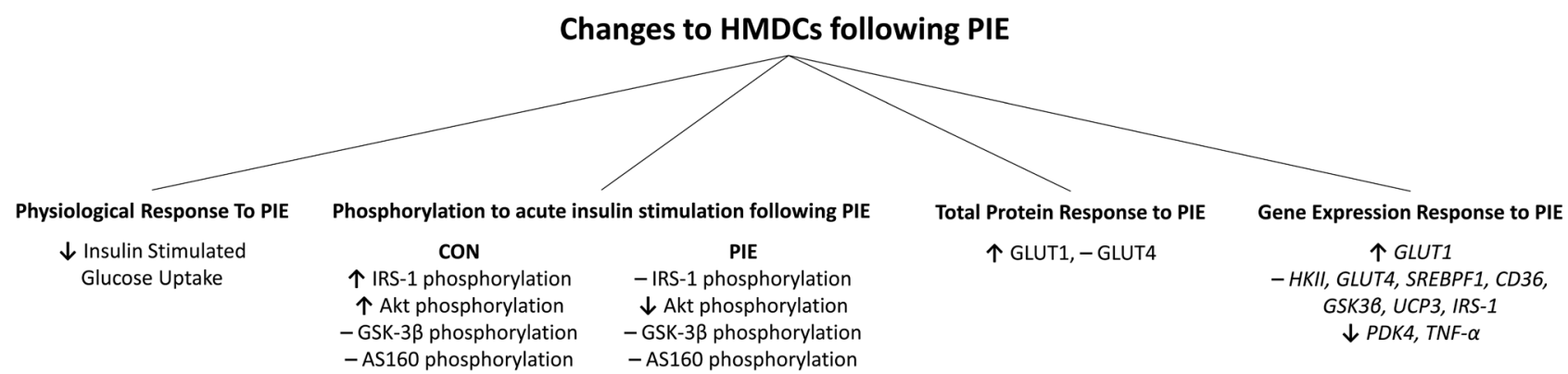

Figure 6

Summary of human muscle-derived cell (HMDC) responses to prolonged insulin exposure (PIE) as a model of hyperinsulinaemia-induced insulin resistance.

resistance in healthy HMDCs, it might not contribute to the transcriptional changes which have previously been observed in disease states (Ducluzeau et al. 2001). These changes could be mediated by other factors, such as lowgrade chronic inflammation and the expression of proinflammatory cytokines (Ruge et al. 2009).

With the previously documented role of hyperinsulinaemia in skeletal muscle insulin resistance, for the first time these experiments were able to confirm previous findings that PIE can attenuate insulinstimulated glucose uptake, attenuate insulin signalling and induce compensatory changes in glucose transporter expression in HMDCs from healthy donors (Fig. 6). While we appreciate that the concentrations of insulin used in these experiments are in excess of physiological hyperinsulinaemia in humans and therefore further experiments would elude to impact of lower insulin concentrations upon skeletal muscle insulin sensitivity in vitro, these findings provide insight into the specific impact of hyperinsulinaemia-induced insulin resistance in primary human skeletal muscle cells.

\section{Declaration of interest}

The authors declare that there is no conflict of interest that could be perceived as prejudicing the impartiality of the research reported.

\section{Funding}

The research was supported by the National Institute for Health Research (NIHR) Leicester Biomedical Research Centre. The views expressed are those of the authors and not necessarily those of the NHS, the NIHR or the Department of Health and Social Care.

\section{Author contribution statement}

M C T performed the experiments. M C T and M P L developed the experiments. M C T, E A, D J P, C J H and N R W M analysed the data. R A F and $\mathrm{P} W$ took the skeletal muscle biopsies from which M C T, D J P and $N$ R W M extracted and cultured the cells. All authors read and approved the final manuscript for submission.

(c) 2020 Society for Endocrinology Published by Bioscientifica Ltd. Printed in Great Britain

\section{Acknowledgements}

The authors would like to thank all the subjects for their time and participation in this research and Dr Carl Hulston for providing the IRS-1 antibodies and input into the manuscript.

\section{References}

Aas V, Bakke SS, Feng YZ, Kase ET, Jensen J, Bajpeyi S, Thoresen GH \& Rustan AC 2013 Are cultured human myotubes far from home? Cell and Tissue Research 354 671-682. (https://doi.org/10.1007/s00441013-1655-1)

Cen H, Botezelli JD \& Johnson JD 2019 Modulation of Insr and insulin receptor signaling by hyperinsulinemia in vitro and in vivo. bioRxiv 556571. (https://doi.org/10.1101/556571)

Ciaraldi TP, Abrams L, Nikoulina S, Mudaliar S \& Henry RR 1995 Glucose transport in cultured human skeletal muscle cells. Regulation by insulin and glucose in nondiabetic and non-insulindependent diabetes mellitus subjects. Journal of Clinical Investigation 96 2820-2827. (https://doi.org/10.1172/JCI118352)

Corkey BE 2012 Banting lecture 2011: hyperinsulinemia: cause or consequence? Diabetes 61 4-13. (https://doi.org/10.2337/db11-1483)

Cusin I, Terrettaz J, Rohner-Jeanrenaud F, Zarjevski N, AssimacopoulosJeannet F \& Jeanrenaud B 1990 Hyperinsulinemia increases the amount of GLUT4 mRNA in white adipose tissue and decreases that of muscles: a clue for increased fat depot and insulin resistance. Endocrinology 127 3246-3248. (https://doi.org/10.1210/endo-127-63246)

Del Prato S, Leonetti F, Simonson DC, Sheehan P, Matsuda M \& DeFronzo RA 1994 Effect of sustained physiologic hyperinsulinaemia and hyperglycaemia on insulin secretion and insulin sensitivity in man. Diabetologia 37 1025-1035. (https://doi.org/10.1007/ BF00400466)

Dietze D, Koenen M, Röhrig K, Horikoshi H, Hauner H \& Eckel J 2002 Impairment of insulin signaling in human skeletal muscle cells by co-culture with human adipocytes. Diabetes 51 2369-2376. (https:// doi.org/10.2337/diabetes.51.8.2369)

Ducluzeau PH, Perretti N, Laville M, Andreelli F, Vega N, Riou JP \& Vidal H 2001 Regulation by insulin of gene expression in human skeletal muscle and adipose tissue: evidence for specific defects in Type 2 diabetes. Diabetes 50 1134-1142. (https://doi.org/10.2337/ diabetes.50.5.1134)

Ferguson RA, Hunt JEA, Lewis MP, Martin NRW, Player DJ, Stangier C, Taylor CW \& Turner MC 2018 The acute angiogenic signalling response to low-load resistance exercise with blood flow restriction. European Journal of Sport Science 18 397-406. (https://doi.org/10.1080 /17461391.2017.1422281)

Gaster M, Schrøder HD, Handberg A \& Beck-Nielsen H 2001 The basal kinetic parameters of glycogen synthase in human myotube cultures 
are not affected by chronic high insulin exposure. Biochimica et Biophysica Acta 1537 211-221. (https://doi.org/10.1016/S09254439(01)00071-0)

Henry RR, Abrams L, Nikoulina S \& Ciaraldi TP 1995 Insulin action and glucose metabolism in nondiabetic control and NIDDM subjects. Comparison using human skeletal muscle cell cultures. Diabetes $\mathbf{4 4}$ 936-946. (https://doi.org/10.2337/diab.44.8.936)

Henry RR, Ciaraldi TP, Mudaliar S, Abrams L \& Nikoulina SE 1996 Acquired defects of glycogen synthase activity in cultured human skeletal muscle cells: influence of high glucose and insulin levels. Diabetes 45 400-407. (https://doi.org/10.2337/diab.45.4.400)

Kanety H, Moshe S, Shafrir E, Lunenfeld B \& Karasik A 1994 Hyperinsulinemia induces a reversible impairment in insulin receptor function leading to diabetes in the sand rat model of noninsulin-dependent diabetes mellitus. PNAS 91 1853-1857. (https:// doi.org/10.1073/pnas.91.5.1853)

Karlsson HKR, Zierath JR, Kane S, Krook A, Lienhard GE \& Wallberghenriksson H 2005 Insulin-stimulated phosphorylation of the Akt substrate diabetic subjects. Diabetes 54 1692-1697. (https://doi. org/10.2337/diabetes.54.6.1692)

Kim YI, Lee FN, Choi WS, Lee S \& Youn JH 2006 Insulin regulation of skeletal muscle PDK4 mRNA expression is impaired in acute insulinresistant states. Diabetes 55 2311-2317. (https://doi.org/10.2337/ db05-1606)

Kramer HF, Witczak CA, Taylor EB, Fujii N, Hirshman MF \& Goodyear LJ 2006 AS160 regulates insulin- and contraction-stimulated glucose uptake in mouse skeletal muscle. Journal of Biological Chemistry $\mathbf{2 8 1}$ 31478-31485. (https://doi.org/10.1074/jbc.M605461200)

Krook A, Roth RA, Jiang XJ, Zierath JR \& Wallberg-Henriksson H 1998a Insulin-stimulated Akt kinase activity is reduced in skeletal muscle from NIDDM subjects. Diabetes 47 1281-1286. (https://doi. org/10.2337/diab.47.8.1281)

Krook A, Digby J, O'Rahilly S, Zierath JR \& Wallberg-Henriksson H $1998 b$ Uncoupling protein 3 is reduced in skeletal muscle of NIDDM patients. Diabetes 47 1528-1531. (https://doi.org/10.2337/ diabetes.47.9.1528)

Kumar N \& Dey CS 2003 Development of insulin resistance and reversal by thiazolidinediones in $\mathrm{C} 2 \mathrm{C} 12$ skeletal muscle cells. Biochemical Pharmacology 65 249-257. (https://doi.org/10.1016/S00062952(02)01509-5)

Mäkinen S, Nguyen YH, Skrobuk P \& Koistinen HA 2017 Palmitate and oleate exert differential effects on insulin signalling and glucose uptake in human skeletal muscle cells. Endocrine Connections 6 331-339. (https://doi.org/10.1530/EC-17-0039)

Marangou AG, Weber KM, Boston RC, Aitken PM, Heggie JC, Kirsner RL, Best JD \& Alford FP 1986 Metabolic consequences of prolonged hyperinsulinemia in humans. Evidence for induction of insulin insensitivity. Diabetes 35 1383-1389. (https://doi.org/10.2337/ diab.35.12.1383)

McAinch AJ, Cornall LM, Watts R, Hryciw DH, O'Brien PE \& CameronSmith D 2015 Increased pyruvate dehydrogenase kinase expression in cultured myotubes from obese and diabetic individuals. European Journal of Nutrition 54 1033-1043. (https://doi.org/10.1007/s00394014-0780-2)

Nikoulina SE, Ciaraldi TP, Abrams-Carter L, Mudaliar S, Park KS \& Henry RR 1997 Regulation of glycogen synthase activity in cultured skeletal muscle cells from subjects with type II diabetes: role of chronic hyperinsulinemia and hyperglycemia. Diabetes $\mathbf{4 6}$ 1017-1024. (https://doi.org/10.2337/diab.46.6.1017)

Osawa H, Sutherland C, Robey RB, Printz RL \& Granner DK 1996 Analysis of the signaling pathway involved in the regulation of hexokinase II gene transcription by insulin. Journal of Biological Chemistry 271 16690-16694. (https://doi.org/10.1074/ jbc.271.28.16690)

Page MM \& Johnson JD 2018 Mild suppression of hyperinsulinemia to treat obesity and insulin resistance. Trends in Endocrinology and Metabolism 29 389-399. (https://doi.org/10.1016/J.TEM.2018.03.018)

Postic C, Leturque A, Rencurel F, Printz RL, Forest C, Granner DK \& Girard J 1993 The effects of hyperinsulinemia and hyperglycemia on GLUT4 and hexokinase II mRNA and protein in rat skeletal muscle and adipose tissue. Diabetes 42 922-929. (https://doi.org/10.2337/ diab.42.6.922)

Rome S, Clément K, Rabasa-Lhoret R, Loizon E, Poitou C, Barsh GS, Riou JP, Laville M \& Vidal H 2003 Microarray profiling of human skeletal muscle reveals that insulin regulates approximately 800 genes during a hyperinsulinemic clamp. Journal of Biological Chemistry 278 18063-18068. (https://doi.org/10.1074/jbc. M300293200)

Ruge T, Lockton JA, Renstrom F, Lystig T, Sukonina V, Svensson MK \& Eriksson JW 2009 Acute hyperinsulinemia raises plasma interleukin-6 in both nondiabetic and type 2 diabetes mellitus subjects, and this effect is inversely associated with body mass index. Metabolism: Clinical and Experimental 58 860-866. (https://doi.org/10.1016/j. metabol.2009.02.010)

Shanik MH, Xu Y, Skrha J, Dankner R, Zick Y \& Roth J 2008 Insulin resistance and hyperinsulinemia: is hyperinsulinemia the cart or the horse? Diabetes Care 31 (Supplement 2) S262-S268. (https://doi. org/10.2337/dc08-s264)

Taniguchi CM, Emanuelli B \& Kahn CR 2006 Critical nodes in signalling pathways: insights into insulin action. Nature Reviews: Molecular Cell Biology 7 85-96. (https://doi.org/10.1038/nrm1837)

Templeman NM, Skovsø S, Page MM, Lim GE \& Johnson JD 2017 A causal role for hyperinsulinemia in obesity. Journal of Endocrinology 232 R173-R183. (https://doi.org/10.1530/JOE-16-0449)

Turner MC, Player DJ, Martin NRW, Akam EC \& Lewis MP 2018 The effect of chronic high insulin exposure upon metabolic and myogenic markers in $\mathrm{C} 2 \mathrm{C} 12$ skeletal muscle cells and myotubes. Journal of Cellular Biochemistry 119 5686-5695. (https://doi. org/10.1002/jcb.26748)

Walker PS, Ramlal T, Donovan JA, Doering TP, Sandra A, Klip A \& Pessin JE 1989 Insulin and glucose-dependent regulation of the glucose transport system in the rat L6 skeletal muscle cell line. Journal of Biological Chemistry 264 6587-6595.

Walker PS, Ramlal T, Sarabia V, Koivisto UM, Bilan PJ, Pessin JE \& Klip A 1990 Glucose transport activity in L6 muscle cells is regulated by the coordinate control of subcellular glucose transporter distribution, biosynthesis, and mRNA transcription. Journal of Biological Chemistry $2651516-1523$.

Wallberg-Henriksson H, Zierath JR, Krook A, Digby J \& O'Rahilly S 2007 Uncoupling protein 3 is reduced in skeletal muscle of NIDDM patients. Diabetes 47 1528-1531. (https://doi.org/10.2337/ diabetes.47.9.1528)

Received in final form 20 December 2019

Accepted 10 January 2020

Accepted Manuscript published online 10 January 2020 https://jme.bioscientifica.com https://doi.org/10.1530/JME-19-0169 (c) 2020 Society for Endocrinology Published by Bioscientifica Ltd. Printed in Great Britain 